\title{
NUCLEOCYTOPLASMIC TRANSLOCATION OF RNA IN TETRAHYMENA PYRIFORMIS AND ITS INHIBITION BY ACTINOMYCIN D AND CYCLOHEXIMIDE
}

\author{
W. A. ECKERT, ${ }^{1}$ W. W. FRANKE and U. SCHEER \\ Division of Membrane Biology and Biochemistry, Institute of Experimental Pathology, \\ German Cancer Research Center, D-69 Heidelberg, and Department of Cell Biology, \\ Institute of Biology II, University of Freiburg, D-78 Freiburg, BRD
}

\begin{abstract}
SUMMARY
The nucleocytoplasmic translocation of RNA pulse-labelled with ${ }^{3} \mathrm{H}$-uridine was studied in logarithmically growing Tetrahymena pyriformis GL cells during a subsequent chase period, without or with actinomycin (AMD) or cycloheximide $(\mathrm{CH})$, by light and electron microscopic autoradiography and analysis of RNA by electrophoresis, and in isolated cell fractions (nuclei, nuclear membranes, nuclear non-membrane bulk material, microsomes, and post-microsomal fractions). Kinetic changes in nucleocytoplasmic transfer of RNA as well as changes of RNA contents and fine structure brought about by AMD and $\mathrm{CH}$ are described. Both antibiotics applied at concentrations inhibitory to RNA synthesis effectively inhibited the nucleocytoplasmic translocation of pre-existing nuclear RNA and resulted in relative accumulation of stable RNA moieties, especially of precursors of rRNA, in the macronucleus. The marked stability of the apparent primary transcription product of the nucleoli (about 2.2 million D mol. wt) indicated that neither considerable processing nor degradation took place during $90 \mathrm{~min}$ of chase in the presence of both drugs. RNA with the molecular weights of mature rRNA (1.32 and 0.7 million D) was not found in substantial amounts in purified macronuclei from normal cells but was detected in the nuclei from AMD-treated cells. AMD completely inhibited nucleocytoplasmic migration of pulse-labelled RNA, the onset of this event being correlated with the time needed for a complete inhibition of ${ }^{3} \mathrm{H}$-uridine incorporation at a particular drug concentration. With $\mathrm{CH}$, however, even when applied at relatively high concentrations, a residual translocation amounting to $15-20 \%$ of that of controls was maintained throughout the chase period.
\end{abstract}

It is widely agreed that in eukaryotes RNA species functioning in the translation process are synthesized in the nucleus, then processed, assembled with specific proteins (at least in the case of $\mathrm{m}$ - and rRNAs), and are finally translocated into the cytoplasm (see e.g. [1]). However, kinetic data on the nucleocytoplasmic transfer of RNA are rather sparse, and, in

\footnotetext{
${ }^{1}$ Present address: Department of Physiology, Institute of Zoology, University of Heidelberg, D-69 Heidelberg, BRD.
}

particular, quantitative data are lacking as to its interdependence with the transcription and translation processes. Some studies using cycloheximide have indicated that the appearance of new ribosomal subunits in the cytoplasm is reduced (e.g. [2]), and that precursors of ribosomal RNA (rRNA) become accumulated in the nucleus [3-5]. According to other authors, however, the processing of already synthesized RNA during a chase in the presence of cycloheximide is not influenced, at least in mammalian cells $[6,7]$, and RNA transport as 
such should not depend on further protein synthesis [8-10]. Results with actinomycin $\mathrm{D}$ are also contradictory and equivocal. Some authors report, for example, a partial or total cessation of nucleocytoplasmic transfer of newly synthesized RNA after inhibition of transcription with this antibiotic (e.g. $[4,10-13])$ whereas others did not find such a dependence (e.g. [9]).

It was the aim of the present study to kinetically and biochemically examine the interdependence of maturation and transfer of newly synthesized RNA, primarily of rRNA, on the continuation of transcription and translation by following the nucleocytoplasmic distribution of ${ }^{3} \mathrm{H}$-uridine pulse-labelled RNA during chase periods, with or without inhibitors present. For this study we have chosen logarithmically growing cultures of the ciliate Tetrahymena pyriformis (strain GL), since this cell system is well known for its especially high nucleocytoplasmic RNA transport rate (e.g. [14-15, 57]).

\section{MATERIAL AND METHODS}

\section{Cultures}

Cells of Tetrahymena pyriformis GL (amicronucleate) were cultivated for $12-15 \mathrm{~h}$ at $28^{\circ} \mathrm{C}$, either in Kapsenberg flasks with $50 \mathrm{ml}$ or in Fernbach flasks with $200-600 \mathrm{ml}$ of a $2 \%(\mathrm{w} / \mathrm{v})$ proteose peptone medium, supplemented with $0.4 \%(\mathrm{w} / \mathrm{v})$ liver extract. Cell density was in the range of 2 to $5 \times 10^{4}$ cells $/ \mathrm{ml}$, corresponding to the exponential phase of growth.

\section{Incorporation- and chase experiments}

In order to determine the effect of the antibiotics on uridine and leucine incorporation, $200 \mathrm{ml}$ of $\log$ phase cultures were divided in portions of $50 \mathrm{ml}$. Indicated amounts of the specific antibiotic and of ${ }^{3} \mathrm{H}$-uridine (uridine- $5-{ }^{3} \mathrm{H}$, Radiochemical Centre, Amersham, England) or ${ }^{3} \mathrm{H}$-leucine (L-leucine-4-5- ${ }^{3} \mathrm{H}$, same source), respectively, were added to give a final concentration of $0.5-1.0 \mu \mathrm{Ci} / \mathrm{ml}$. The antibiotics were omitted in the controls. At time intervals $5 \mathrm{ml}$ samples were removed from each tube and cells were precipitated with $1 \mathrm{ml}$ of ice-cold $50 \%$ trichloracetic acid (TCA). The pelleted material was then washed 3 times with $5 \%$ TCA, and was finally resuspended in $1 \mathrm{ml}$ of distilled water. One aliquot $(0.2 \mathrm{ml})$ was dissolved in solubilizer (NCS, Nuclear Chicago), mixed with $5 \mathrm{ml}$ of a toluene-based scintillation fluid, and the radioactivity was determined in a Packard Tri-Carb liquid scintillation spectrometer. Another aliquot was dissolved in $1 \mathrm{M}$ $\mathrm{NaOH}$ and protein was determined [16]. In the pulse-chase experiments cells were collected from $400-600 \mathrm{ml}$ cultures by centrifugation at $4000 \mathrm{~g}$ for 3 min. The cell sediment was resuspended in $10 \mathrm{ml}$ medium and $10 \mathrm{ml}$ of culture medium with ${ }^{3} \mathrm{H}$-uridine was added to give a final radioactivity of $20-30 \mu \mathrm{Ci} / \mathrm{ml}$. After $8 \mathrm{~min}$ of incubation at $28^{\circ} \mathrm{C}$ the cells were sedimented for $3 \mathrm{~min}$ at $3000 \mathrm{~g}$ and washed once with about $50 \mathrm{ml}$ of fresh culture medium. A small aliquot was removed and prepared for autoradiography. The cells were then incubated in two Fernbach flasks with $100 \mathrm{ml}$ of fresh culture medium containing $0.1 \mu \mathrm{M}$ non-labelled uridine, i.e. a concentration corresponding to that in the preceding radioactive incubation. One of the flasks contained the antibiotic at the indicated concentration. At time intervals aliquots of $25 \mathrm{ml}$ were removed from either flask, mixed with the same volume of ice-cold culture medium, and sedimented at $4000 \mathrm{~g}$ in the cold. The cell pellets were then processed for autoradiography. For determining the specific radioactivity of the RNA of the various cell fractions and their molecular weights by gel electrophoresis, $1200 \mathrm{ml}$ cultures were used and the pulse labelling was done with $0.5-2 \mu \mathrm{Ci} / \mathrm{ml}$ or $20-25 \mu \mathrm{Ci} / \mathrm{ml}{ }^{3} \mathrm{H}$-uridine, respectively. After $90 \mathrm{~min}$ of chase the cells were sedimented in the cold and fractionated as described later.

\section{Electron microscopy}

Cells and cell fractions were fixed as pellets and processed for ultrathin section studies as described previously $[17,18]$.

\section{Autoradiography}

Light and electron microscopic autoradiography was carried out as described in detail elsewhere [18].

\section{Cell fractionation and chemical determinations}

Cell fractions and macronuclear subfractions were prepared and analysed as described in a previous communication [18].

\section{Preparation of RNA}

Phenol extraction of RNA was carried out using a modification of Kirby's procedure [19]. The fractions were incubated in $5-10 \mathrm{ml}$ of TNS-lysis medium (2\% w/v triisopropylnaphthalenesulphonate, $1 \% \mathrm{w} / \mathrm{v}$ $\mathrm{NaCl}, 0.05 \mathrm{M}$ Tris, $\mathrm{pH}$ 7.6) and homogenized with a Potter-Elvehjem homogenizer for $10 \mathrm{~min}$ at $0^{\circ} \mathrm{C}$. The lysate was vigorously shaken with an equal volume of phenol-cresol ( $500 \mathrm{~g}$ redistilled phenol, $70 \mathrm{~g}$ redistilled $m$-cresol, $0.5 \mathrm{~g} \mathrm{8}$-hydroxyquinoline) for $5 \mathrm{~min}$, and the phases were separated by centrifugation at $4000 \mathrm{~g}$ for $10 \mathrm{~min}$ at $4^{\circ} \mathrm{C}$. After removal of the phenol phase, $1 \mathrm{ml}$ 


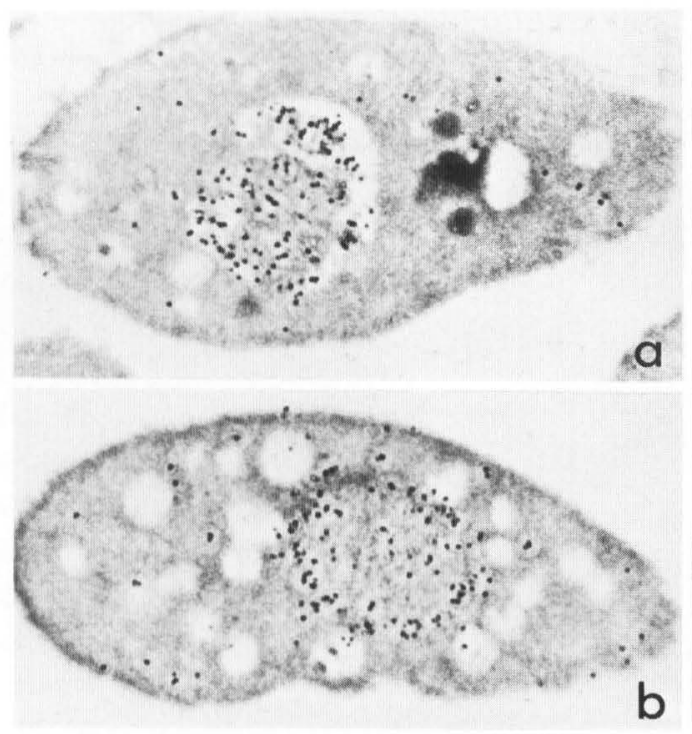

Fig. 1. Light microscopic autoradiographs of thin sections $(1 \mu \mathrm{m})$ of Tetrahymena pyriformis cells pulselabelled for $8 \mathrm{~min}$ with ${ }^{3} \mathrm{H}$-uridine $(a, b)$ and subsequently chased with $0.1 \mu \mathrm{m}$ unlabelled uridine in the culture medium for $90\left(a^{\prime}\right)$ and $120 \mathrm{~min}\left(b^{\prime}\right)$, respective-

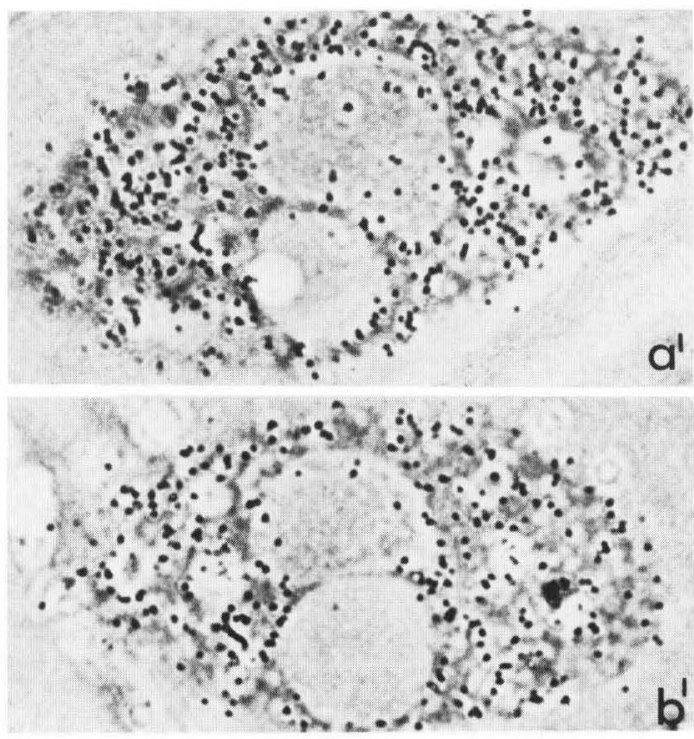

ly. Note the high macronuclear grain density after the pulse labelling $(a, b)$ and the disappearance of most of the nuclear label during the chase period $\left(a^{\prime}, b^{\prime}\right)$. $(a$, b) $\times 1500 ;\left(a^{\prime}, b^{\prime}\right) \times 1800$. of a $3 \mathrm{M} \mathrm{NaCl}$ solution was added per $10 \mathrm{ml}$ of the aqueous phase, and the mixture was briefly shaken. Then 1 vol of the phenol-cresol mixture was added and the whole was shaken and centrifuged. Then equal parts of the phenol-cresol mixture and chloroform were added to the collected aqueous phase, and this mixture was also shaken and centrifuged. The supernatant was carefully removed, mixed with 2 vol of ethanol and stored at $-20^{\circ} \mathrm{C}$ overnight. To remove any phenol (for $\mathrm{OD}_{260}$ determination of RNA) the precipitate was pelleted at $4000 \mathrm{~g}$, redissolved in $0.01 \mathrm{M}$ sodium acetate buffer ( $\mathrm{pH} 5.0$ ) containing $0.5 \%$ sodium dodecyl sulfate (SDS) and $1 \mu \mathrm{g} / \mathrm{ml}$ polyvinyl sulphate (PVS) and reprecipitated by adjusting the solution to $0.1 \mathrm{M} \mathrm{NaCl}$ and to $66 \%$ ethanol, followed by storage for at least $4 \mathrm{~h}$ at $-20^{\circ} \mathrm{C}$. This precipitation step was repeated twice. For removal of DNA the first precipitate was dissolved in a small volume of $10 \mathrm{mM}$ Tris- $\mathrm{HCl}$ buffer ( $\mathrm{pH} 7.4$ ) and mixed with an equal volume of a solution containing $40 \mu \mathrm{g} / \mathrm{ml}$ deoxyribonuclease I (ribonuclease-free, Worthington Biochemicals, Freehold) in the same buffer with $3 \mathrm{mM}$ $\mathrm{MgCl}_{2}$ added. The incubation was $10 \mathrm{~min}$ at room temperature. Alternatively nucleic acids in the isolated macronuclei were freed by digestion and lysis with 1 $\mathrm{mg} / \mathrm{ml}$ pronase (Calbiochem, B grade, predigested at $37^{\circ} \mathrm{C}$ for at least $\left.30 \mathrm{~min}\right)$ in $0.02 \mathrm{M}$ Tris buffer ( $\left.\mathrm{pH} 7.4\right)$ containing $0.5 \%(\mathrm{w} / \mathrm{v})$ SDS for $10 \mathrm{~min}$ at room temperature. The lysate was made $0.1 \mathrm{M}$ with respect to $\mathrm{NaCl}$, and nucleic acids were precipitated. Finally the RNA was dissolved in electrophoresis buffer with $0.2 \%$ SDS. In some controls the RNA was digested with $100 \mu \mathrm{g} / \mathrm{ml}$ heat pretreated ribonuclease (Serva Feinbiochemica, Heidelberg).

\section{Electrophoresis}

Slabs of $0.5 \%$ agarose, $2.25 \%$ acrylamide composite gels were prepared according to Ringborg et al. [20]. About $20 \mu \mathrm{g}$ of RNA dissolved in electrophoresis buffer containing $0.2 \%$ SDS (in ca $20 \mu \mathrm{l}$ ) were introduced into each of the two slits in the gel. In most cases one trace was used for reference Tetrahymena rRNA. Sometimes co-precipitated ${ }^{14} \mathrm{C}$-uridine labelled Xenopus laevis rRNA prepared as described elsewhere [21] was used as an internal molecular weight marker. When no internal marker RNA was used the two bands of the reference rRNA were marked under UV-light at $254 \mathrm{~nm}$. The gel slices $(1.1 \mathrm{~mm})$ were transferred into counting vials and $10 \mathrm{ml}$ of scintillation fluid containing NCS-solubilizer ( $50 \mathrm{ml} / 1$, Nuclear Chicago) was added. Radioactivity was corrected for blank values and in the double isotope preparations for channel spillover.

\section{RESULTS}

\section{Autoradiography of pulse-chase} experiments with ${ }^{3} \mathrm{H}$-uridine

After brief pulse labelling the ${ }^{3} \mathrm{H}$-uridine radioactivity incorporated is almost totally 


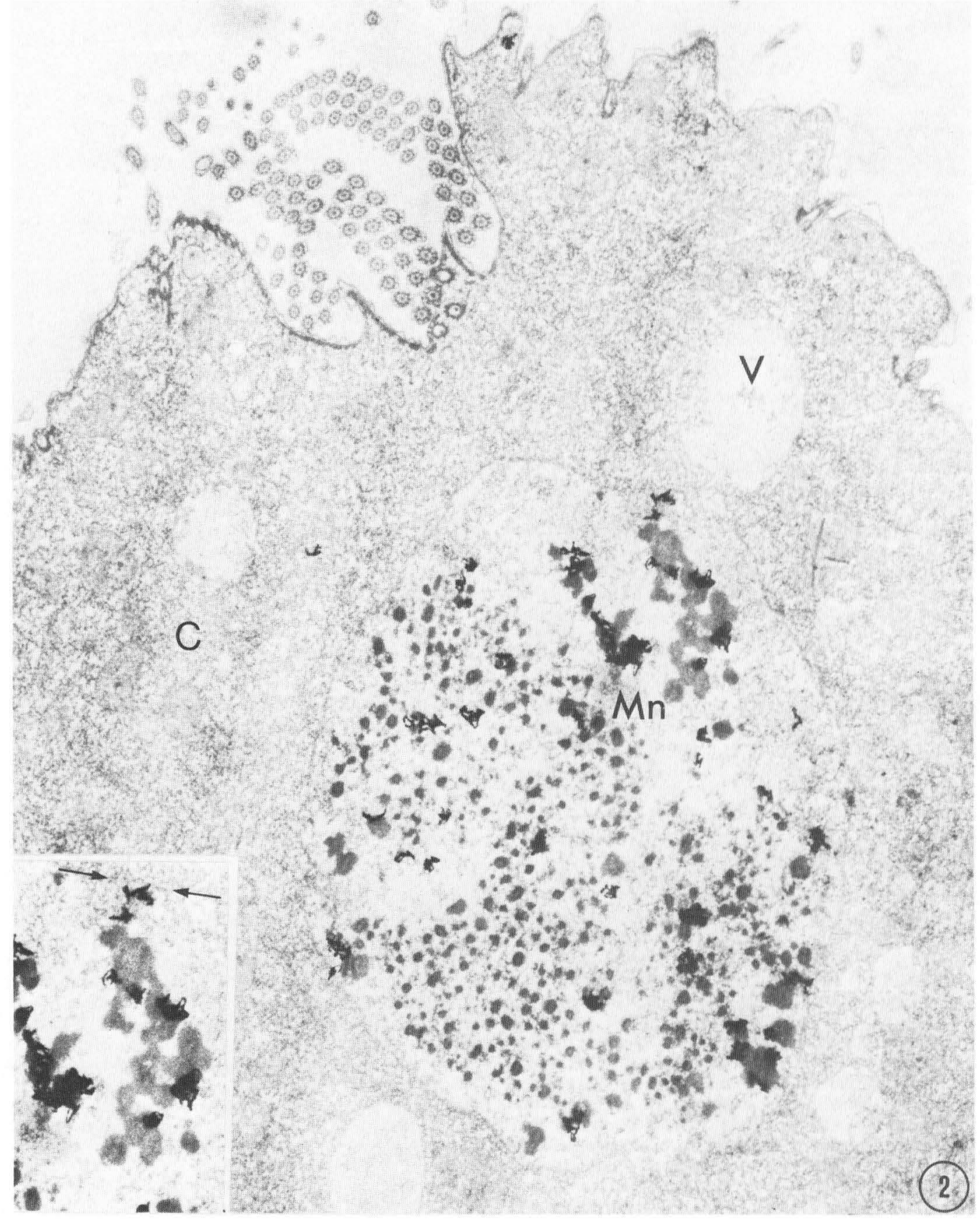

Fig. 2. Electron microscopic autoradiograph of a $8 \mathrm{~min}$ pulse-labelled Tetrahymena cell demonstrating the high silver grain density over the macronucleus $(M n)$, in contrast to the low density of label in the cytoplasm
(C). The majority of nuclear silver grains are associated with the nucleolar aggregates (inset). The pair of arrows in the inset denotes the level of the adjacent nuclear envelope. $V$, vacuole, $\times 7000$; inset, $\times 10000$. 
confined to the macronucleus. Light $\mathrm{mi}$ croscopic autoradiographs of cells which were pulse-labelled for $8 \mathrm{~min}$ (fig. $1 a, b$ ) show a high labelling density of the macronucleus, in contrast to the cytoplasm where the silver grains (SG) are just becoming significant above background. In many sections a preferential SG accumulation is revealed over the nuclear periphery (e.g. fig. $1 b)$, corresponding to the normal position of the nucleoli in Tetrahymena cells (e.g. [22]). This situation is even better illustrated in electron microscopic autoradiographs (fig. 2). A quantitative evaluation of such electron micrographs showed that at this pulse label stage about $60 \%$ of the SG were clearly associated with the nucleoli, whereas the remaining ones lie over chromatin or 'nuclear sap' or could not be unequivocally attributed to any nuclear component (see [18]).

When such pulse-labelled cells were washed free from radioactive uridine and transferred into fresh medium supplemented with non-radioactive uridine ('chase') the nucleocytoplasmic distribution of incorporated radioactivity, i.e. of newly synthesized RNA, changed rapidly. After 20-30 min of chase, the SG density was about equal over nucleus and cytoplasm, and after $90-120 \mathrm{~min}$ the macronuclei were almost devoid of SG, in contrast to the heavy accumulation of label in the cytoplasm (fig. $1 a^{\prime}, b^{\prime}$ ). Electron microscopic autoradiography revealed that the few SG still detectable in the nuclei were almost equally distributed over chromatin and the peripheral regions of the nucleoli [18]. The results of SG counts over cells of such chase experiments are presented in fig. $3 a$ as SG per unit area versus chase period. After a brief interval of increase of label over the nucleus, which reflects the exhaustion of the labelled pre- cursor pool, one notes an exponential decrease, somewhat concomitant with a continuous increase of cytoplasmic label density that reached its maximum at about 60 min of chase. In semilogarithmic plots the decrease of nuclear SG density was always linear between 20 and about $70 \mathrm{~min}$ of chase, whereupon the remaining label decreased much more slowly (fig. $3 a^{\prime}$ ). This linear intercept follows a regression equation of the type $y=\ln a-b x$, thus indicating a uniform first order kinetic (see Appendix). We have determined, in six different pulsechase experiments using exponentially growing Tetrahymena pyriformis GL, the average values of the rate constants for the decrease of nuclear grain densities ( $k=$ $3.1 \pm 0.3 \times 10^{-2} \mathrm{~min}^{-1}$ ) and the rate constant of cytoplasmic SG increase $\left(k^{\prime}=7.3 \pm 1.1\right.$ $\left.\times 10^{-3} \mathrm{~min}^{-1}\right)$. Assuming that degradation is uniform and negligible and that no further incorporation of radioactivity from the precursor pool occurs after $20 \mathrm{~min}$ one should expect that $k$ and $k^{\prime}$ differ mainly in proportion to the distribution coefficient between nucleus and cytoplasm, i.e. by the volume ratio of nucleus and cytoplasm which is about $1: 32$ in these cells [23]. One notes, however, that the experimentally determined values of $k$ and $k^{\prime}$ differ much less (by a factor of about 4; see Discussion). One can also express the change of label distribution between the two compartments during a chase by following the ratio of the specific nuclear and cytoplasmic grain densities

$\left(R_{t}=\frac{G_{\mathrm{N} t}}{G_{\mathrm{C} t}}\right.$

table 1, for evaluation see ref. [24]).

Relatively high doses of actinomycin D (AMD) are required for rapid and complete inhibition of RNA synthesis in this amicro- 


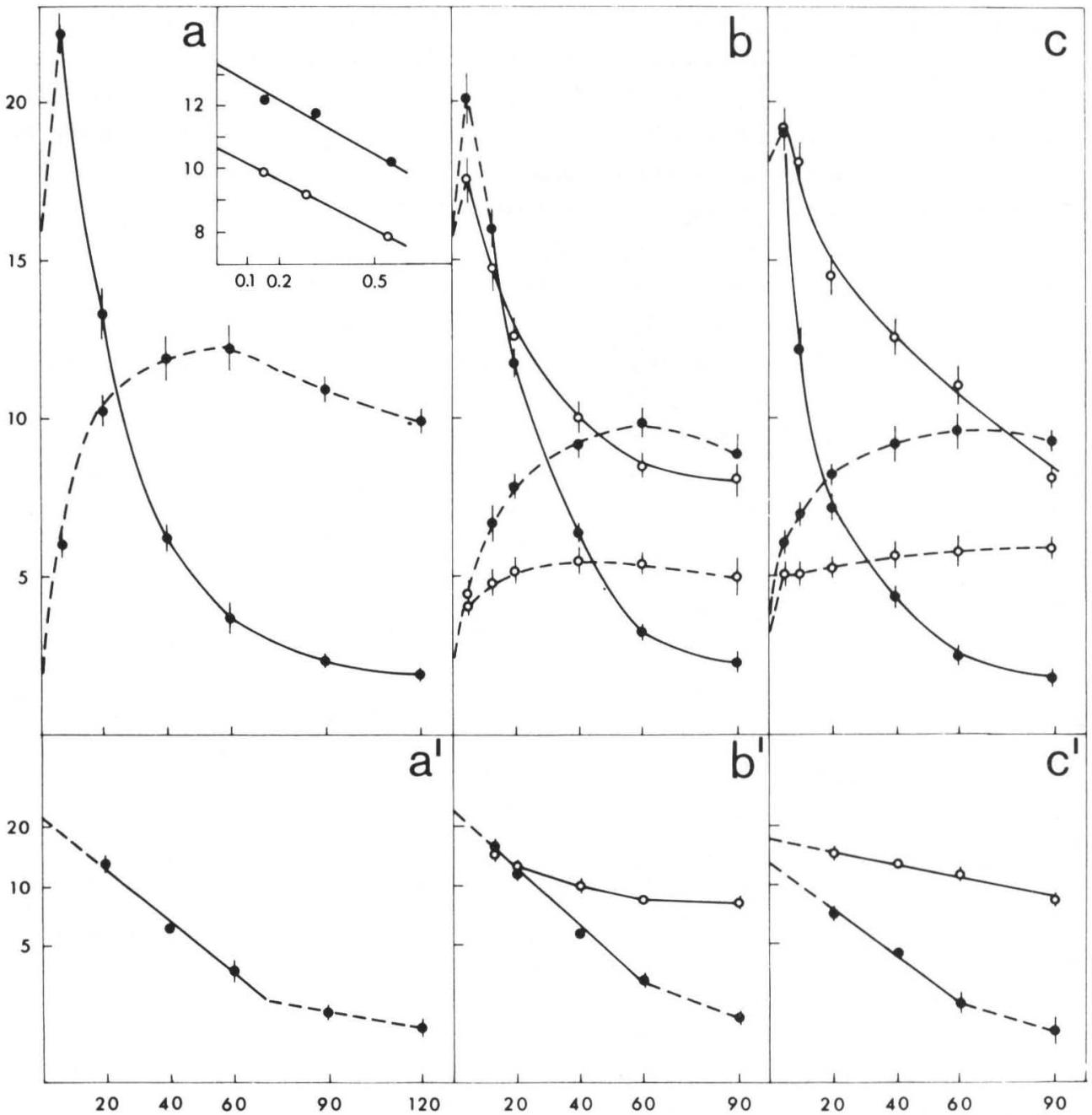

Fig. 3. Abscissa: time of chase (min); $1 / e^{k t}$ (inset in $a$ ); ordinate: $(a-c)$ silver grains $(S G)$ per unit area; $\left(a^{\prime}-c^{\prime}\right)$ $\log \mathrm{SG} / \mathrm{unit}$ area; $G_{c}$ (inset).

$(a, b, c)$ Time course of nuclear $(-)$ and cytoplasmic $(--)$ grain densities during a chase without $(O)$ and in the presence of $(O)$ the specific antibiotic; $(b, 50 \mu \mathrm{g} / \mathrm{ml}$ AMD; $c, 100 \mu \mathrm{g} / \mathrm{ml} \mathrm{CH}$ ).
(Inset) Plots of cytoplasmic grain densities $\left(G_{c}\right)$ vs time of chase. $\left(a^{\prime}, b^{\prime}, c^{\prime}\right)$ Semi-logarithmic plots of nuclear grain densities vs time of chase. Control cells; $\mathrm{O}-\mathrm{O}$, cells treated with the specific antibiotic $\left(b^{\prime}, \mathrm{AMD} ; c^{\prime}, \mathrm{CH}\right)$. The linear portion of the curve in $\left(a^{\prime}\right)$ between 20 and about $70 \mathrm{~min}$ of chase corresponds to the regression line $y=1 \mathrm{n} 22.7-0.013 x$. nucleate strain $[18,25]$. The viability of the cells is not seriously influenced for several hours with these drug concentrations. Inhibition of RNA synthesis in the macronuclei was usually accompanied by fusions of the nucleolar units into large aggregates which frequently revealed a typical segre- gated appearance $[18,22]$. Light and electron microscopic autoradiographs of cells collected at $90 \mathrm{~min}$ of chase in the presence of $50 \mu \mathrm{g} / \mathrm{ml}$ AMD, i.e. a concentration fully inhibitory to RNA synthesis within $10 \mathrm{~min}$, showed a marked nuclear retention of label $[18,24]$. Grain counts (e.g. table 1, fig. $3 b$ ) 
Table 1. Grain densities over nucleus and cytoplasm in autoradiograms of sections of ${ }^{3} \mathrm{H}$ uridine pulse labelled Tetrahymena cells after various times of chase without or in the presence of $50 \mu \mathrm{g} / \mathrm{ml} \mathrm{AMD}$ and $100 \mu \mathrm{g} / \mathrm{ml} \mathrm{CH}$, respectively

Time of chase $(t)$

\begin{tabular}{lllllll}
\hline 0 & 5 & 10 & 20 & 40 & 60 & 90
\end{tabular}

\section{Control}

Nucleus (N)

Cytoplasm (C)

$R_{t}=N / C$

$1 / e^{k t a}$

Actinomycin $(50 \mu \mathrm{g} / \mathrm{ml})$

$\begin{array}{rl}15.7 \pm 0.6 & 20.1 \pm 0.8 \\ 2.2 \pm 0.2 & 4.5 \pm 0.3 \\ & 4.46\end{array}$

$15.7 \pm 0.6$

$2.2 \pm 0.2$

Cytoplasm

$R_{t}$

\section{Control}

Nucleus

Cytoplasm

$R_{t}$

$1 / e^{k t a}$

Cycloheximide $(100 \mu \mathrm{g} / \mathrm{ml})$

$\begin{array}{lccccccc}\text { Nucleus } & 18.4 \pm 0.7 & 19.3 \pm 0.6 & 18.1 \pm 0.7 & 14.5 \pm 0.6 & 12.6 \pm 0.5 & 11.1 \pm 0.7 & 8.1 \pm 0.3 \\ \text { Cytoplasm } & 3.3 \pm 0.4 & 5.1 \pm 0.4 & 5.1 \pm 0.4 & 5.3 \pm 0.3 & 5.7 \pm 0.4 & 5.8 \pm 0.5 & 5.9 \pm 0.3 \\ R_{t} & & 3.77 & 3.58 & 2.66 & 2.22 & 1.92 & 1.48 \\ 1 / e^{k t a} & & & & 0.85 & 0.73 & 0.61 & \end{array}$

Cultures of cells were pulse-labelled with ${ }^{3} \mathrm{H}$-uridine for $8 \mathrm{~min}$, then divided into two portions and incubated into fresh growth medium containing $0.1 \mu \mathrm{M}$ unlabelled uridine and none (control) or the specific antibiotic at the indicated concentration. At the times indicated aliquots were removed from both portions of the cultures and prepared for autoradiography. For each value the silver grains (SG) of, respectively, $25 \mu^{2}$ nuclear and cytoplasmic area ('unit area') from 20-30 cells were counted (standard errors are given).

a For definition see Appendix.

revealed that concentrations of 20 and 50 $\mu \mathrm{g} / \mathrm{ml}$ effectively interfered with the distribution of RNA label [18,24]. At $20 \mu \mathrm{g} / \mathrm{ml}$ AMD an accumulation of nuclear label, relative to the control, was recognizable between 20 and $30 \mathrm{~min}$ of chase, and at $50 \mu \mathrm{g} / \mathrm{ml}$ this accumulation was notable even at about $15 \mathrm{~min}$. It is clear that the true onset of the relative accumulation of nuclear label must be somewhat earlier because of the influence of this AMD concentration on the uptake of radioactivity from the precursor pool. A semilog plot of nuclear grain density versus time (e.g. fig. $3 b^{\prime}$ ) revealed a gradual reduction in the decrease of nuclear label ending at an al- most constant label density at $60-90 \mathrm{~min}$. The appearance of label in the cytoplasm (fig. $3 b$ ) is likewise inhibited but the time course of this inhibition does not correspond to the decrease of nuclear label by attaining zero at about 13 (at $50 \mu \mathrm{g} / \mathrm{ml}$ ) or $20 \mathrm{~min}$ (at $20 \mu \mathrm{g} / \mathrm{ml}$ ) of chase. These results suggest a correlation between the onset of retention of newly synthesized RNA in the nucleus, the cessation of appearance of labelled RNA in the cytoplasm, and the complete inhibition of uridine incorporation. Such a correlation would also explain the lack of influence on the chase kinetics with $10 \mu \mathrm{g} / \mathrm{ml}$ AMD, at which concentration a total inhibition of ${ }^{3} \mathrm{H}$-uridine in- 
corporation is not reached before $60 \mathrm{~min}$ of incubation [18]. That prolonged treatment with even this low concentration of AMD, however, interferes with the nucleocytoplasmic distribution of uridine-label incorporated into RNA was demonstrated by the significantly higher $R_{t}$-values $(0.9-1.0)$ obtained after $200 \mathrm{~min}$ in the continuous presence of the tritiated nucleoside, compared to control cells after $90 \mathrm{~min}$ of chase $(0.2-$ 0.3 ; table 1).

It has been noted by various authors that cycloheximide $(\mathrm{CH})$ is not only potent in inhibiting translation but also leads to a marked inhibition of nuclear RNA synthesis and processing (e.g. [2, 3, 5, 7, 26]). We have found that the inhibition of uridine incorporation in these cells was even stronger than that of leucine incorporation, even at concentrations of $1 \mu \mathrm{g} / \mathrm{ml}$ and lower at which adaptation can occur [18, $24,27]$. CH concentrations of $10 \mu \mathrm{g} / \mathrm{ml}$ and higher nearly completely inhibit protein as well as RNA synthesis $[18,24]$. Since $\mathrm{CH}$ is not inhibitory to ${ }^{3} \mathrm{H}$-UTP incorporation in vitro into the RNA fraction of isolated macronuclei $[18,24]$ it is reasonable to assume that, as in mammalian cells (e.g. [7, 26]), the RNA inhibition is a consequence of the cessation of cytoplasmic protein synthesis. Autoradiographs of cells treated during a chase period with effective doses of $\mathrm{CH}[18,24]$ showed a pronounced relative accumulation of nuclear label (see table 1 and fig. $3 c$ ). When the SG values over nuclear units were transferred into a semilogarithmic plot versus time (fig. $3 c^{\prime}$ ) first order kinetics were apparent, as in the control, though with a decreased rate constant. The decrease of nuclear label was constant up to $90 \mathrm{~min}$ of chase. A sharp transition in the curve of cytoplasmic labelling (fig. $3 c$ ) is recognized already at 5 min of chase and indicates that the presence of $\mathrm{CH}$ rapidly reduces the shift of radioactive RNA from nucleus to cytoplasm. The true onset of this inhibitory action could be extrapolated to $3 \mathrm{~min}$ [24]. Since nuclear label decreased in the presence of $\mathrm{CH}$ with first order kinetics the rate constant of cytoplasmic label increase $\left(k^{\prime}\right)$ could be calculated (see Appendix) using the regression line (fig. $3 c^{\prime}$ ) and extrapolation of $G_{\mathrm{Cmax}}$ from the plot of $G_{c^{-}}$ values vs $1 / e^{k t}$ (as in fig. $3 a$ ) as being about $15-20 \%\left(k^{\prime}=1.3-1.4 \times 10^{-3} \mathrm{~min}^{-1}\right)$ of control values [24]. This 'residual' transport rate is also preserved in the presence of $1 \mathrm{mg} / \mathrm{ml} \mathrm{CH}$.

\section{Biochemical determinations}

The specific radioactivity of RNA after ${ }^{3} \mathrm{H}$-uridine incorporation was first determined in isolated macronuclei, in total 'cytoplasmic particulate fraction', and in the cytoplasmic $100000 \mathrm{~g}$ supernatant (for composition data of these fractions see ref. [18]). The specific radioactivities in the presence of either AMD or $\mathrm{CH}$ after 90 min of chase (table 2) demonstrated a substantially higher RNA radioactivity in the nuclear fraction, corresponding to a decrease in the cytoplasmic fractions. It is noteworthy that the specific radioactivity of the soluble cytoplasmic fraction which contains the transfer RNAs is, with both drugs, approximately as high as in the controls. When the isolated macronuclei were extracted with high salt concentrations two residual fractions were obtained by sucrose gradient centrifugation, the nuclear membrane band and a residual pellet still containing nucleolar material (for compositions see ref. [18]). The nuclear membranes contained relatively little RNA, which is indicative of the removal of most of both nucleolar and ribosomal RNAs (cf $[28,29])$ but still showed identifiable pore 
Table 2. Specific radioactivities (cpm/mg RNA) in subfractions of pulse-labelled Tetrahymena cells after 90 or 60 min (the two right-hand columns) of chase with and without actinomycin $D(50 \mu \mathrm{g} / \mathrm{ml})$ or cycloheximide $(100 \mu \mathrm{g} / \mathrm{ml})$ present

\begin{tabular}{llllll}
\hline Chase conditions & $\begin{array}{l}\text { Macro- } \\
\text { nuclei }\end{array}$ & $\begin{array}{l}\text { Cytoplasmic } \\
\text { fraction }\end{array}$ & $\begin{array}{l}\text { Soluble } \\
\text { fraction }\end{array}$ & $\begin{array}{l}\text { Nuclear } \\
\text { membrane }\end{array}$ & \multicolumn{1}{c}{$\begin{array}{l}\text { Nuclear } \\
\text { residue }\end{array}$} \\
\hline Actinomycin added & 91315 & 8710 & 3056 & 310000 & 150140 \\
Cycloheximide added & 43791 & 10059 & 2655 & 111375 & 71360 \\
Control & 14268 & 18125 & 2638 & 112500 & 22300 \\
\hline
\end{tabular}

complex components. The specific radioactivities of RNA in these fractions after $60 \mathrm{~min}$ of chase (table 2) showed a relative increase of label in the nuclear envelope in the presence of AMD but not with $\mathrm{CH}$. In these experiments the specific activities indicated an enrichment of pulse-labelled RNA in the nuclear membrane compared with the residual fraction.

The gel-electrophoretic radioactivity pattern of the nuclear RNA isolated after an 8 min pulse labelling (fig. $4 a$ ) reveals a variety of molecular sizes [30, 31]. A typical pattern indicating the predominance of rRNA precursor molecules is apparent after $20 \mathrm{~min}$ of chase (fig. $4 b$ ) with prominent peaks of putative rRNA precursors at about 2.2, 1.42-1.45, and 1.0 million D and some intermediate components in the region of 1.75-1.55 million $\mathrm{D}$, the latter being, however, somewhat variably expressed in different experiments. Under nondenaturing conditions the Tetrahymena cytoplasmic ribosomal RNAs appeared with molecular weights of 1.32 and 0.70 million D (fig. $4 c$; for similar mol. wt determinations see [32]). It was significant that substantial amounts of such mature rRNA were not present in our isolated macronuclei. After $90 \mathrm{~min}$ of chase (fig. $4 d$ ) only very little radioactivity is found in the region of the apparent pre-rRNA but distinct peaks are still visible in regions corresponding to RNA molecular sizes of ca
1.44 and 0.8 million D which perhaps represent immediate precursors to the mature rRNAs. Noteworthy is again the almost absence of fully mature rRNAs in the nuclei. When AMD was present during the chase period an enormous accumulation of radioactivity in the pre-rRNA region $\left(2.2 \times 10^{6} \mathrm{D}\right)$ was noted (fig. $5 a$ ), together with peaks corresponding to molecular weights of ca $1.75,1.41$ and 1.02 million D and some indication of material corresponding to the mature (1.32 million D) large rRNA. Concomitant with this relative accumulation of radioactivity in rRNA precursors we noted a decreased radioactivity in the cytoplasmic rRNAs (fig. 5b). A similar but much lower accumulation of radioactivity was notable when the chase was carried out in the presence of $\mathrm{CH}$ (fig. 5c), with the consistent appearance of a heavy shoulder in the pre-rRNA peak indicative of the existence of some larger molecules. The inhibition of appearance of ${ }^{3} \mathrm{H}$-uridine radioactivity in the cytoplasmic ribosomes was less with $\mathrm{CH}$ than with AMD (fig. $5 d$ ), in correspondence with the autoradiographic data.

Chemical analyses showed an average RNA content per logarithmically growing Tetrahymena cell of about 242 pg ([18]; for related references, see [18]). The macronuclear RNA content under our isolation conditions was consistently about $2.4 \%(5.7 \mathrm{pg})$ of that of the total cell. The 


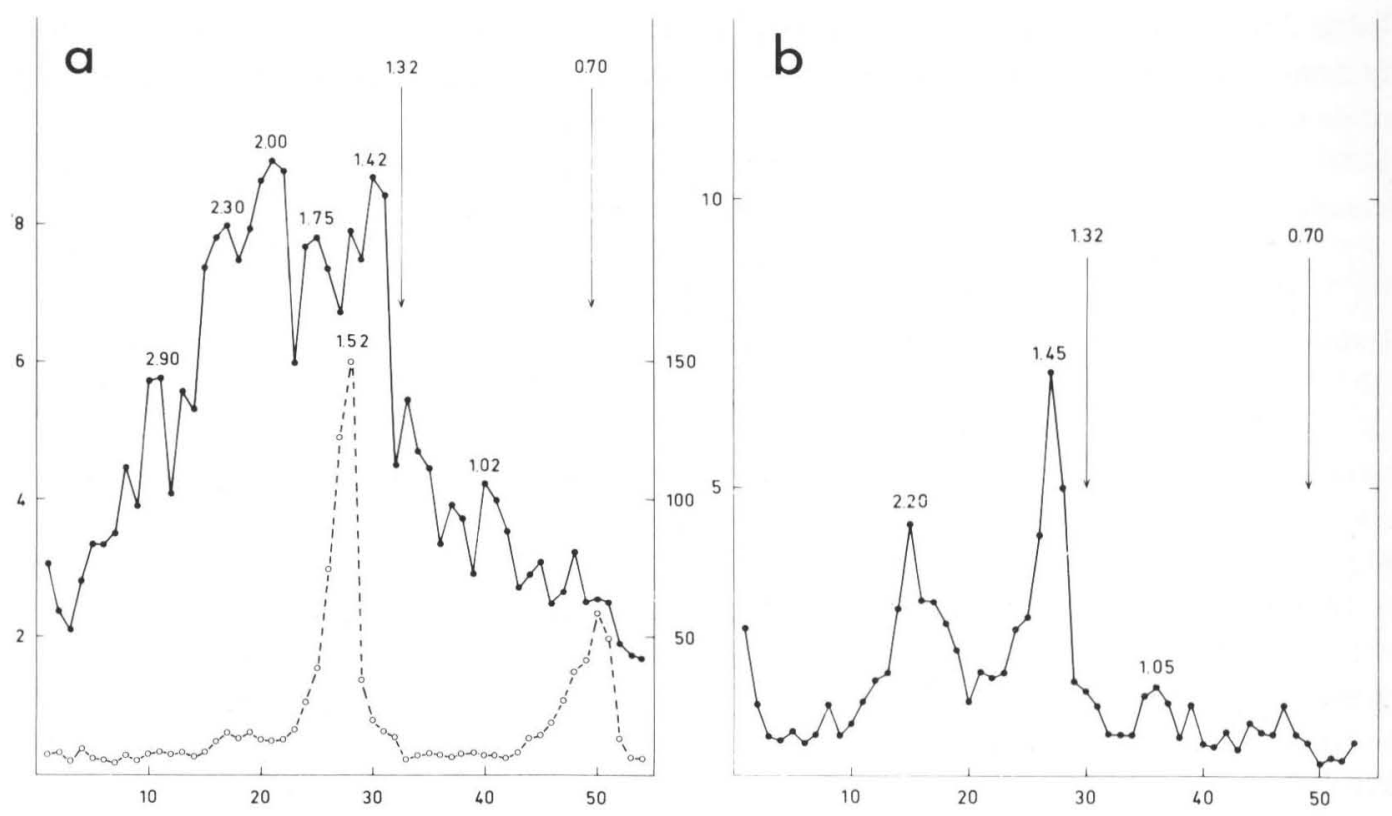

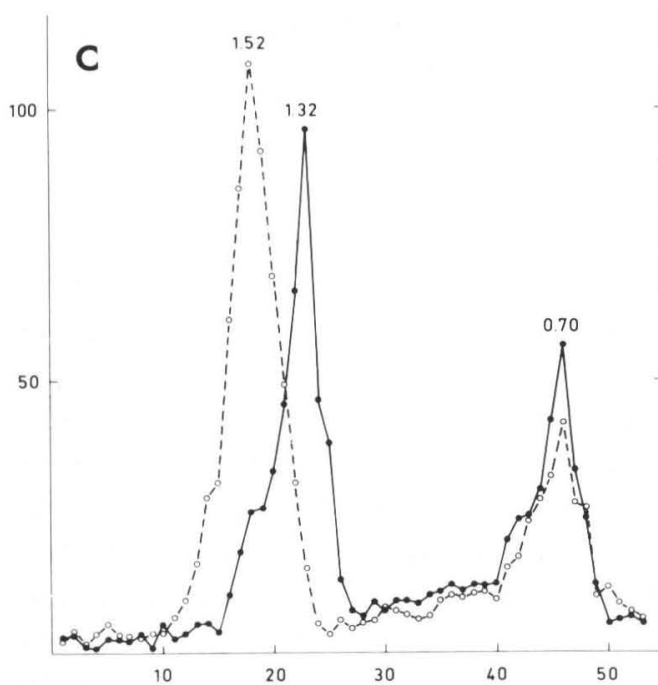

Fig. 4. Abscissa: slice no.; ordinate: (left) (c) ${ }^{3} \mathrm{H} \mathrm{cpm}$, $(a, b, d){ }^{3} \mathrm{H} \mathrm{cpm}\left(\times 10^{-2}\right)$; (right) $(a, c){ }^{14} \mathrm{C} \mathrm{cpm}$.

Separation of nuclear and microsomal RNA from Tetrahymena pyriformis on $0.5 \%$ agarose, $2.25 \%$ acrylamide composite gels. Logarithmically growing cells were collected and incubated in $20 \mathrm{ml}$ of culture medium containing ${ }^{3} \mathrm{H}$-uridine $(25 \mu \mathrm{Ci} / \mathrm{ml})$ for $8 \mathrm{~min}$, washed free from the radioactive nucleotide and transferred to fresh culture medium containing $0.1 \mu \mathrm{M}$ unlabelled uridine ('chase'). After various periods, macronuclei and microsomes were prepared and RNA isolated by pronase-sodium dodecyl sulphate digestion or a phenol-cresol method modified from Kirby [19].

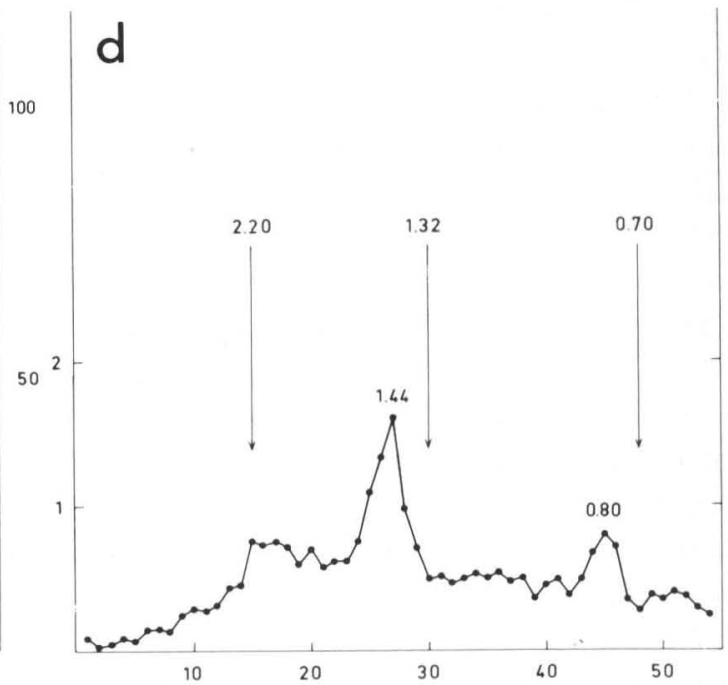

(a) Radioactivity pattern of nuclear RNA obtained after the pulse-labelling of $8 \mathrm{~min}(-)$. For reference, ${ }^{14} \mathrm{C}$-uridine labelled Xenopus laevis rRNA was coelectrophorized (O- - $O$ ). The positions of unlabelled Tetrahymena rRNA run in parallel are indicated by the arrows. The numbers at the peaks indicate the molecular weights in $10^{6} \mathrm{D}$. (b) Pattern of nuclear RNA obtained after a subsequent chase of $20 \mathrm{~min}$. (c) Comparison of the Tetrahymena microsomal rRNA obtained after $20 \mathrm{~min}$ of chase in coelectrophoresis with ${ }^{14} \mathrm{C}$-labelled Xenopus laevis rRNA. (d) Nuclear pattern after $90 \mathrm{~min}$ of chase. Note the small amount of radioactivity in the region of the apparent pre-rRNA. 
presence of both drugs, AMD and $\mathrm{CH}$, for $90 \mathrm{~min}$ resulted in an almost identical decrease in the cellular RNA content by about $15 \%$, corresponding to an average half-life of whole cell RNA (about $85 \%$ rRNA) of about $5 \mathrm{~h}$, in agreement with other determinations [24, 34, 35]. The contents of DNA, protein and lipids did not change significantly. The effect on the nuclear RNA content was different with both drugs; after AMD treatment it decreased by about $40 \%$ whereas with $\mathrm{CH}$ it was only negligibly reduced [18].

From these data the 'turnover rate constant' of nuclear RNA (cf [15]), i.e. the portion of the nuclear RNA translocated into the cytoplasm per min, can be approximately calculated by the formula $k^{+}=$ $(a+d) \cdot n^{-1}$ in which $a$ is the exponential growth constant which is $4.6 \times 10^{-3}$ per min assuming a generation time of $150 \mathrm{~min}, d$ is the degradation constant which is $2.9 \times 10^{-3}$ per min on the basis of an overall $t / 2$ of cytoplasmic RNA of $5 \mathrm{~h}$, and $n$ is the ratio of nuclear to cytoplasmic RNA content $(0.0256) . k^{+}$as estimated using these values is 0.29 per $\mathrm{min}$, i.e. about $1.65 \mathrm{pg}$ of RNA is translocated into the cytoplasm per min. This value is very close to the independently determined figure of $1.72 \mathrm{pg}$ calculated from the cytoplasmic RNA content per cell (236 pg) and the autoradiographically determined value of the rate constant of cytoplasmic label increase $\left(k^{\prime}\right.$; see above) and the figure of $1.84 \mathrm{pg}$ which was used in calculations of the mean nuclear pore flow rates $[14,28]$. The calculated $k^{+}$value would correspond to a turnover time $\left(T_{\mathrm{T}}=1 / k^{+}\right.$, i.e. the average duration time of potential cytoplasmic RNA molecules in the nucleus) of nuclear RNA molecules of about $3.7 \mathrm{~min}$ which is in accord with the calculations of turnover and processing times for macronuclear pre-
rRNA reported by other authors [15, 31, $36,57]$. From the amount of ribosomal units synthesized and translocated into the cytoplasm per min (about $5 \times 10^{5}$; see also [15]), the number of rRNA cistrons in the macronucleus (170-200; refs $[53,54])$, the average number of simultaneously growing chains per cistron (ca 100; assuming a situation similar to what has been shown in various other organisms, 55; for refs, see [38]), the chain growth rate of rRNA can be estimated to be at least 50 nucleotides per second (for similar data in other eukaryotes see [56]). This means that the apparent rRNA precursor molecule $\left(2.2 \times 10^{6}\right.$ D) needs max. 2 min for completion. Therefore, after a pulse period of $8 \mathrm{~min}$ most of the radioactivity in the macronuclei should be present in completed chains (for a discussion of the influence of pulse duration on RNA transport inhibition by AMD see [33]).

\section{DISCUSSION}

The formation of rRNA in Tetrahymena appears essentially to follow the pattern reported for some plant cells [38]. The apparent primary rRNA precursor molecule has a mol. wt of about 2.2 million $\mathrm{D}$ which seems to correspond to earlier findings of a 34-35 S pre-rRNA in Tetrahymena [30, 31]. Under the assumption of a common precursor for both ribosomal RNAs, the tentative processing scheme based upon our separations in non-denaturing gels then might be:

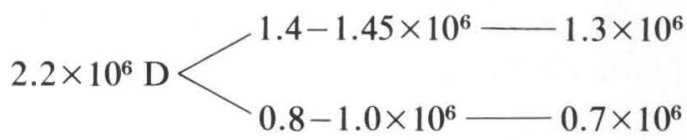

Such a pattern would imply that the total loss of nucleotides is less than $15 \%$. Further our data suggest that either the final 

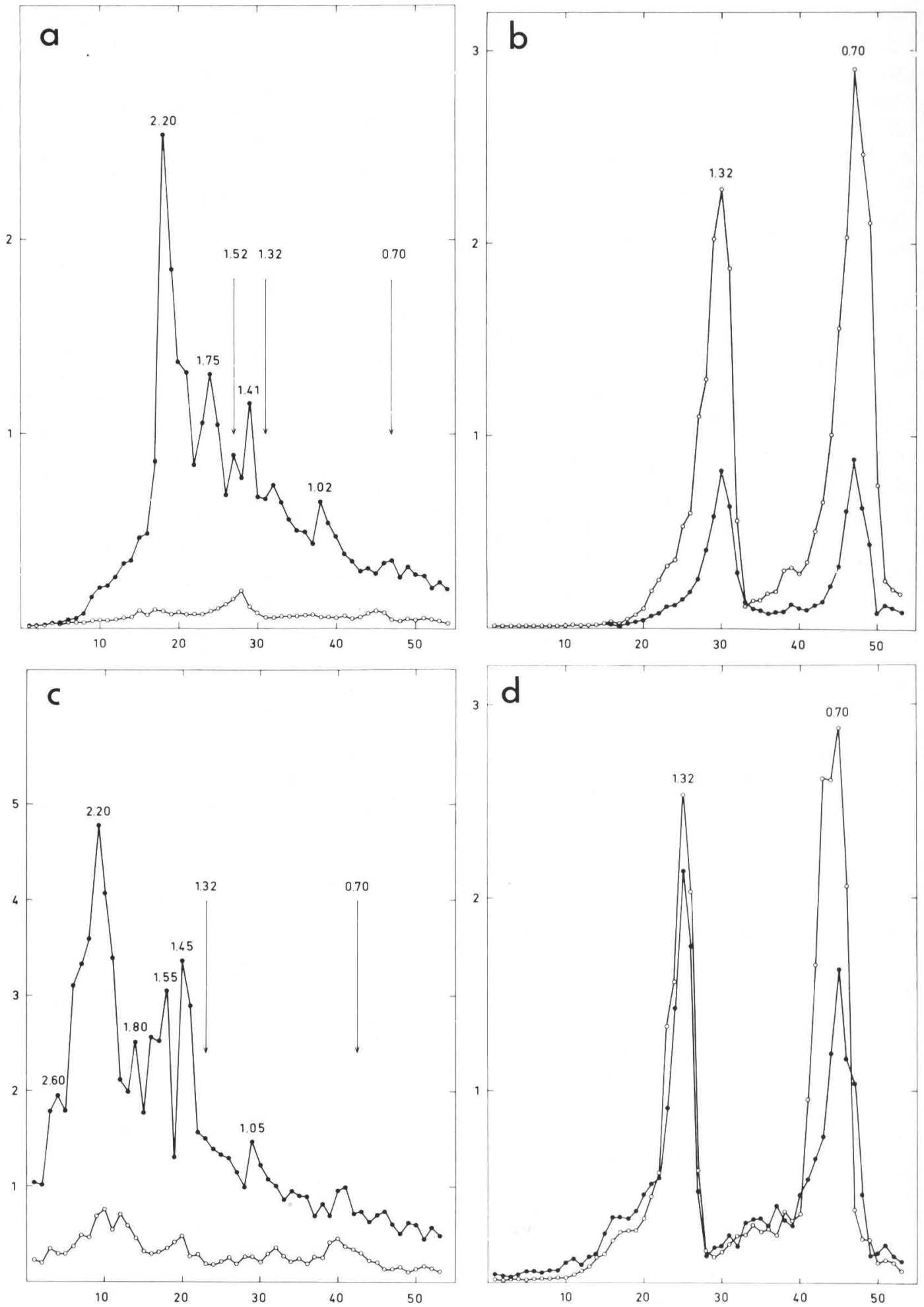

Exptl Cell Res 94 (1975) 
stages of rRNA processing do not take place within the macronucleus or the translocation of rRNA into the cytoplasm is extremely fast. Our finding of the virtual absence of mature rRNAs in the macronuclei is in contrast to most current compartmentalization schemes of rRNA formation based mainly on findings with mammalian cells (e.g. $[1,39])$ but compares well with a great many findings in various cell systems $[21,28,38,40-43]$.

The great efficiency of the apparently strictly vectorial nucleocytoplasmic transport of RNA in Tetrahymena is demonstrated not only by the high turnover rate constant of nuclear RNA $\left(k^{+}\right)$but also by the calculations of nuclear pore flow rates of RNA (for review see [28, 44]) and the present autoradiographic determinations of cytoplasmic label kinetics. The rate constant of the increase of cytoplasmic labelling $k^{\prime}\left(7.3 \pm 1.1 \times 10^{-3}\right.$ per $\left.\mathrm{min}\right)$ is in agreement with the sum of the exponential growth rate constant and the degradation constant of total cellular RNA (see Results) and therefore might be considered as a relevant expression of the nucleocytoplasmic translocation rate of RNA. The rate of the coincident decrease of nuclear label $(k)$ appears to be much slower, probably the reflection of the 'pool effect', i.e. the continuing incorporation of labelled nucleotides from the cellular pool, which simulates a longer retention of pulse-labelled RNA in the nucleus. The transition observed in the curves of nuclear label at

Fig. 5. Abscissa: slice no.; ordinate: $(a, b, d) \mathrm{cpm}$ $\left(\times 10^{-3}\right) ;(c) \mathrm{cpm}\left(\times 10^{-2}\right)$.

Radioactivity profiles of nuclear and microsomal RNA from Tetrahymena cells obtained after $90 \mathrm{~min}$ of chase in the presence of $50 \mu \mathrm{g} / \mathrm{ml} \operatorname{AMD}(a, b)$ and 100 $\mu \mathrm{g} / \mathrm{ml} \mathrm{CH}(c, d)$, respectively. For controls, the RNA of the corresponding fraction from untreated cells was run in parallel $(O)$. about $60-70 \mathrm{~min}$ of chase roughly coincides with the time of pool depletion [45] and probably reflects the end of nucleocytoplasmic transport of the bulk of potentially cytoplasmic RNA (note that the turnover time $T_{\mathrm{T}}$ of nuclear RNA is less than 4 min, see Results).

The presence of $\mathrm{CH}$ and AMD during the chase results in a strong reduction or total inhibition of nucleocytoplasmic transfer of newly synthesized RNA, somewhat in agreement with findings in other cell systems (see p. 32). The observed retention of relatively stable uridine-labelled RNA in the nucleus is most dramatic for the $2.2 \times 10^{-6} \mathrm{D}$ pre-rRNA molecules, especially in the case of AMD, indicating that processing of rRNA is seriously influenced. If the $2.2 \times 10^{6} \mathrm{D}$ molecule represents the initial rDNA transcription product in Tetrahymena, then our results with AMD are in contrast to findings, especially with mammalian cells, in which the processing of rRNA has been reported to proceed normally at least down to the 32 (and 18) $\mathrm{S}$ stage (e.g. [13, 43, 46]). The accumulation, relative to controls, of the apparent primary rRNA precursors after inhibition of protein synthesis with $\mathrm{CH}$, however, has also been found in fungal $[5,47]$ and mammalian cells [4], as well as in higher plants [37]. Besides the relative retention of radioactivity in the $2.2 \times 10^{6} \mathrm{D}$ region and a significant higher radioactivity at about 1.40 1.45 and about $1.0 \times 10^{6} \mathrm{D}$ there was also a marked accumulation of radioactivity in components with $1.75-1.80$ and 1.52$1.55 \times 10^{6} \mathrm{D}$, together with a significant appearance of some $1.3 \times 10^{6} \mathrm{D}$ rRNA in the presence of AMD. If these molecules are not products of an aberrant processing but represent accumulated minor intermediates of the normal processing sequence then one would have to postulate the existence of 
longer initial rDNA transcription products in the range of at least $3.2 \times 10^{6} \mathrm{D}$.

In contrast to the relative similarity of the molecular weight pattern of nuclear RNA retained during a chase in the presence of both these antibiotics, the kinetics of changes of nuclear and cytoplasmic label and the decrease of total nuclear RNA content are very different. This might be explained by differences in influencing the nucleocytoplasmic RNA translocation as such and by different interferences with the above-mentioned 'pool effect'. The onset of total inhibition of transcription (i.e. blocking of further incorporation of nucleotides into any species of RNA) by various AMD concentrations has been shown to be correlated with the cessation of appearance of labelled RNA in the cytoplasm. The further decrease of nuclear label and of nuclear RNA content thereafter need not be necessarily explained by an 'AMD-induced' nuclear RNA degradation (e.g. [48, 49]) but might well reflect the physiological degradation of the heterodisperse RNA moiety in the absence of further synthesis (see also $[50,51]$ ). The rapid influence of $\mathrm{CH}$ on nucleocytoplasmic translocation of RNA (with a lag period of only $3 \mathrm{~min}$ ) which is also observed with puromycin [24] indicates that at least some proteins necessary for rRNA transport are newly synthesized and are present in a relative small pool in Tetrahymena. The remaining flow rate of about $15-20 \%$ of the control then might be maintained at the expense of a slow turnover pool which is used, for example, in synchronized Tetrahymena cells for phases of increased ribosome synthesis [52]. The higher specific RNA radioactivity in the nuclear residue fraction but not in the nuclear membrane fraction in the presence of $\mathrm{CH}$ suggests that it is only the rate of rRNA transloca- tion from the nucleoli which is regulated by the protein supply, the subsequent transfer through the nuclear envelope, however, being independent of continued protein synthesis (cf also [10]). On the contrary, our data with AMD indicate that shortly after inhibition of RNA synthesis the transport of RNP through the nuclear envelope is blocked, but the translocation of labelled RNA from the nucleoli to the nuclear envelope continues for some time, possibly resulting in the accumulation of $1.32 \times 10^{6}$ D rRNA at this structure.

\section{REFERENCES}

1. Darnell, J E, Bacteriol rev 32 (1968) 262.

2. Ennis, H L, Mol pharmacol 2 (1966) 543.

3. de Kloet, S R, Biochem j 99 (1966) 566.

4. Yoshikawa-Fukada, M, Biochim biophys acta 145 (1967) 651

5. Viau, J P \& Davis, F F, Biochim biophys acta 209 (1969) 190.

6. Cooper, H L, Nature 227 (1970) 1105.

7. Muramutsu, M, Shimado, N \& Higashinakagawa, T, J mol biol 53 (1970) 91 .

8. Rizzo, A J \& Webb, T E, Eur j biochem 27 (1972) 136.

9. Amos, H, Hoyt, R E \& Horisberger, M, In vitro 6 (1970) 190.

10. Kumar, A \& Wu, R S, J mol biol 80 (1973) 265.

11. Levy, H B, Proc soc exp biol med 113 (1963) 886.

12. Leick, V, Eur j biochem 8 (1968) 215.

13. Stenram, U, Bengtsson, A \& Willen, R, Cytobios 5 (1972) 125.

14. Franke, W W, Naturwiss 57 (1970) 44.

15. Leick, V \& Andersen, S B, Eur j biochem 14 (1970) 460 .

16. Lowry, O H, Rosebrough, N J, Farr, N L \& Randall, R L, J biol chem 193 (1951) 265.

17. Franke, W W, Eckert, W A \& Krien, S, Z Zellforsch 119 (1971) 577.

18. Eckert, W A \& Franke, W W, Cytobiologie. In press.

19. Loening, U E, Biochem j 113 (1969) 131.

20. Ringborg, U, Daneholt, B, Edström, J E, Egyházi, E \& Lambert, B, J mol biol 51 (1970) 327.

21. Scheer, U, Trendelenburg, M F \& Franke, W W, Exp cell res 80 (1973) 175.

22. Satir, B \& Dirksen, E R, J cell biol 48 (1971) 143.

23. Britten, R, Inst Washington year book 59 (1959) 279.

24. Eckert, W A, Dissertation. University Freiburg i Br. (1972).

25. Eckert, W A, Franke, W W \& Scheer, U, Z Zellforsch 127 (1972) 230 . 
26. Summers, W P, Noteboom, W D \& Mueller, G C, Biochem biophys res commun 22 (1966) 399.

27. Frankel, J, J cell physiol 76 (1970) 55.

28. Franke, W W \& Scheer, U, Transport at the cellular level. Symp Brit soc exp biol, vol. 23, p. 249. Cambridge University Press, Cambridge, UK (1974).

29. Kaspar, C B, The cell nucleus (ed H Busch) vol. 1, p. 349. Academic Press, New York and London (1974).

30. Kumar, A, J cell biol 45 (1970) 623.

31. Prescott, D M, Bostock, C, Gamow, E \& Lauth, M, Exp cell res 67 (1971) 124 .

32. Loening, U E, J mol biol 38 (1968) 355.

33. Egyházi, E, Nature 250 (1974) 221.

34. Cleffmann, G, Z Naturforsch 24 b (1969) 1624.

35. Byfield, J E \& Lee, Y G, J protozool 17 (1970) 445.

36. Leick, V, Eur j biochem 8 (1969) 221.

37. Jackson, M \& Ingle, J, Plant physiol 51 (1973) 412.

38. Spring, H, Trendelenburg, F, Scheer, U, Franke, W W \& Herth, W, Cytobiologie 10 (1974) 1.

39. Maden, B E H, Progr biophys mol biol 22 (1971) 127.

40. Ringborg, U \& Rydlander, L, J cell biol 51 (1971) 355 .

41. Udem, S A \& Warner, J R, J biol chem 248 (1973) 1412.

42. Gall, J G, Natl cancer inst monogr 23 (1966) 475.

43. Penman, S, J mol biol 17 (1966) 117.

44. Franke, W W \& Scheer, U, The cell nucleus (ed H Busch) vol. 1, p. 220. Academic Press, New York and London (1974).

45. Jacobson, K B \& Prescott, D M, Exp cell res 36 (1964) 561 .

46. Weinberg, R A, Loening, U, Willems, M \& Penman, S, Proc natl acad sci US 58 (1967) 1088.

47. Mayo, V S, Andrean, A G \& de Kloet, S R, Biochim biophys acta 168 (1968) 297.

48. Wiesner, R, Acs, G, Reich, E \& Skafic, A, J cell biol 27 (1965) 47.

49. Stewart, G W \& Farber, E, J biol chem 243 (1968) 4479.

50. Plagemann, P G W, J cell physiol 71 (1971) 241.

51. Martin, T W \& McCarthy, B J, Biochim biophys acta 277 (1972) 354.

52. Plesner, P, Exp cell res 67 (1971) 255 A.

53. Engberg, J \& Pearlman, E, Eur j biochem 26 (1972) 393.

54. Yao, M-C, Kimmel, A R \& Gorovsky, M A, Proc natl acad sci US 71 (1974) 3082.

55. Miller, I \& Beatty, B R, Science 164 (1969) 955.

56. Greenberg, H \& Penman, S, J mol biol 21 (1966) 527.

57. Wunderlich, F, J membrane biol 7 (1972) 220.

Received July 8, 1974

Revised version received January 13, 1975

\section{APPENDIX}

The first-order kinetic as indicated by the linear portion in semi-logarithmic plots of nuclear grain densities vs time of chase (fig. 3 ) is described by the differential equation:

$\frac{d G_{\mathrm{N}_{t}}}{d t}=k G_{\mathrm{N}_{t}}$

when $G_{\mathrm{N} t}$ is the SG density at the time $t$ of the chase period and $k$ is the first-order rate constant. With the definition of the initial grain density $G_{\mathrm{N} 0}$ at the starting point $t_{0}$ (i.e. $20 \mathrm{~min}$ of chase duration) integration of eq. (1) yields:

$G_{\mathrm{N}_{t}}=G_{\mathrm{N}_{0}} e^{-k t}$ or: $\ln G_{\mathrm{N}_{t}}=\ln G_{\mathrm{N}_{0}}-k t$.

$k$ is represented by the negative slope of the semilog plots (e.g. fig. $3 a$ ). With $T_{\mathrm{H}}=$ $\ln 2 / k$ then the average half-life of nuclear label, and with $T_{\mathrm{T}}=1 / k=T_{\mathrm{H}} / \ln 2$ the apparent turnover time of labelled nuclear pool of RNA is defined. If one assumes a precursor-product relationship between the nuclear and cytoplasmic labelled RNA the observed increase of cytoplasmic SG density during the chase should be proportional to the specific nuclear SG density:

$$
\frac{d G_{\mathrm{C}_{t}}}{d t}=k^{\prime} G_{\mathrm{N}_{t}}
$$

where $k^{\prime}$ is the rate constant of the increase of the cytoplasmic SG density. Substitution of both eqs (2), (3) then yields:

$$
\frac{d G_{\mathrm{C}_{t}}}{d t}=k^{\prime} G_{\mathrm{N}_{0}} e^{-k t}
$$

If one neglects the degradation of the pulse-labelled cytoplasmic RNA, which is reasonable, for instance, in the initial part of the chase period ( $\mathrm{cf}$ [24]) one obtains by integrating eq. (4) with the condition

$$
G_{\mathrm{C}}=G_{\mathrm{C}_{0}} \text { at } t=0: G_{\mathrm{C}_{t}}=G_{\mathrm{C}_{0}}+G_{\mathrm{N}_{0}} \frac{k^{\prime}}{k}\left(1-e^{-k t}\right)
$$


and, respectively:

$$
G_{\mathrm{C}_{t}}=G_{\mathrm{C}_{0}}+G_{\mathrm{N}_{0}} \frac{k^{\prime}}{k}-G_{\mathrm{N}_{0}} \frac{k^{\prime}}{k} \frac{1}{e^{k t}} .
$$

When such a function is plotted as $G_{\mathrm{C}_{t}}$ vs $1 / e^{k t}$ a straight line is obtained with an ordinate intercept representing $G_{\mathrm{C}_{0}}+G_{\mathrm{N}_{0}} k^{\prime} / k$, i. e. the maximal $G_{\mathrm{C}}\left(G_{\mathrm{C} \text { mai }}\right)$ possible. Such plots of some SG determinations are shown in fig. $3 a$ (inset), in which the extrapolated values of $G_{\mathrm{C} \max }$ represent those cytoplasmic SG densities which would have been reached (5) in the absence of RNA degradation. From $k^{\prime}=\frac{G_{\mathrm{C} \max }-G_{\mathrm{C}_{0}}}{G_{\mathrm{N}_{0}}} k$

(according to $G_{\mathrm{C} \max }=G_{\mathrm{C}_{0}}+G_{\mathrm{N}_{0}} \frac{k^{\prime}}{k}$ ), $k^{\prime}$ can be calculated by experimental parameters. 